\title{
Fostering Trust as a Catalyst for Sustainable Village-Owned State Enterprise
}

\author{
K Srirejeki ${ }^{1}$, A Faturahman ${ }^{1}$, S Supeno $^{1}$ \\ ${ }^{1}$ Universitas Jenderal Soedirman \\ Email:kikysrirejeki@gmail.com
}

\begin{abstract}
While the obligatory mandate to establish Village-Owned State Enterprise (VOE) is final, the fact that there are still many villages do not have VOE yet, lead us to investigate what hamper its establishment. Using an exploratory case studies to several villages in Banyumas district, Central Java, we found that trust and reliance hold as key roles for the success of the establishment as well as the sustainability of VOE. We argue that by fostering trust and reliance among village government officials, rural communities and village-owned enterprise managers would give positive outcomes. Further, this study also shed light on ways to foster trust. The practical implication of our finding shows that for a village leader who wants to have a successful village owned enterprise needs to be able to trust and rely on VillageOwned State Enterprise managers.
\end{abstract}

\section{Introduction}

Data from World Development Indicators 2017, shows that half of the Indonesian are in rural areas. According to Central Bureau Statistics (Badan Pusat Statistik/BPS), 13,8 percent of them are poor, while data from World Bank 68.7 percent of them are classified as poor. In 2014, Indonesia through Village Law had attempted to address this issue. The aims are to advance general welfare, fostering community-based economy and create sociocultural resilience in 74,754 villages. Through this Law, the Indonesian government wants to empower village by strengthening the village position.

Indonesia before the Reformation Era put the village only as the development object. The village did not have power and authorities to manage its resources, and it became a habit because it was being practiced for decades. Currently, there is a shifting paradigm that place village as the subject or actor for its development. The village is hoping to be more independent in managing its resources and solving its problems. To be able to do that, the village is expected to be more independent economically. The village which does not rely on central government donors or subsidy.

Village-Owned State Enterprise is believed to become a very strategic tool to improve the village economy and solve rural problems. VOE is a legal village economic organization established and owned by the village and independently and professionally managed by the separated-management team. VOE's business model allows capital sharing between village government and private party or rural community.

VOE is the pillars of village economic and or social activity. VOE can play the role as the social institution and or commercial institution [18]. VOE in the context of social institution serves a purpose to contribute solutions towards rural social problems. While VOE as the commercial institution plays as the contributor to hold economic activities that can increase the village income (Pendapatan Asli Desa/PaDes).

VOE can be a strategic tool to create an economically-independent village. The economic activities that have been carefully considered and then implemented through VOE can increase the PaDes. In that construct way of thinking, when PaDes can be increased trough VOE, this condition should encourage each village government to respond to the establishment of VOE positively. Not only logically correct, but VOE is also one of the mandatory and consequence of the implementation of the Village Law, it means VOE is also legally required. However, aside from its mandatory nature, recent data in 2017 shows that of 74,954 villages there is only 18,446 VOE. The data shows that the VOE 
establishment rate is only 24,6 percent. Based on this phenomenon gap, the research aim is to investigate what hampers the establishment of VOE. The significance of the research is twofold. First, there are not many research investigating what factors might hamper the establishment of VOE. Most research discussed the importance of VOE and how to improve it, but the main question regarding the phenomenon of why there are many villages do not have VOE yet has not been answered yet. Second, investigating factor that hampers the establishment of VOE is important to find the solution, in a hope, it will cue in how to initiate the establishment of VOE.

\section{Research Method}

The research was done using a qualitative approach, in particular, an exploratory case study research. This method allows us to conduct field research that investigates a current phenomenon within its reallife situation. The benefit of using this method is not only it focuses on the current situation, but also it gives very minimum access of researchers to manipulate the events. This method is also consistent with our analysis in that the research question is about asking how or why certain events occur.

The study focused at a micro and meso level analysis. Micro-level analysis means we analyzed based on single VOE while meso means the level of analysis is on the district level. The interviews with village government officials, VOEs managers, rural dignitaries, and local government authorities were primarily carried out using the semi-structured and in-depth interview. Questions list were openended, which allows interviewees to answer based on their situations. We conduct face-to-face conversations which lasted around one and a half hours for each interview. We recorded the conversations and taken the notes.

To improve the validity and reliability of our findings, we use triangulation technique. Patton (1999) stated that triangulation refers to the use of multiple methods and or data sources in qualitative research to develop a comprehensive understanding of the phenomenon [6]. We gathered empirical information through multiple sources of evidence, interviews as primary data, and as for secondary data, we gathered official documents, website, and press releases.

\section{Result and Discussion}

\subsection{Trust Issue, Lack of Competence, and Structural Vagueness}

Jamil and Askvik [10] argue that trust is a multidimensional concept and has various meanings and applications in the field of social science. However, among various concept of trust, one of the most widely cited definitions of trust is explained by Mayer et al. [15]. He defines trust as the willingness of a party to be vulnerable to the actions of another party based on the expectation that the other party will perform a particular action necessary to the trustier, irrespective of the ability to monitor or control the other party.

Jones and Shah [13] extended Mayer's model of trust by dividing the trust process into three concepts:

1. Trusting actions refers to behavior that demonstrates a reliance on others.

2. Trusting beliefs refers to perceived trustworthiness

3. Trusting intentions refers to the willingness to be vulnerable.

Based on the above model of trust, in the context of this study trust refers to involving belief and hope from village government officials to VOE's managers that they have the competence to manage VOE and act by the village interest. Trust becomes the salient issue that we found on our study. There are many VOE managers feel that village officials do not trust them completely to manage and to develop VOE. Statement from VOE Manager was:

"We do really want to develop VOE, but we feel like VOE establishment was just because village officials do not want to violate the Law, because the Law stated that every village has to have 
VOE. So, basically they (village officials) asked us to develop and manage VOE but our feet are tied, and we cannot move freely. So, we just got stuck."

The frustration keeps on going because on a planning level, the distrust is already in place. The distrust to VOE managers is not only by the Village Leader but also extended to other stakeholders, which seems to be initiated by the Village leader then extended to other stakeholders. One of the VOE managers stated that:

"In a village meeting, we (VOE management) had informed to the village officials and village representative assembly as well as prominent figures about our business idea. But because we have no source of fund, we have to consult every business idea to them, which is okay, because that's how the system works. But what sometimes saddens me is on so many occasions, we ended by forgetting our ideas and surrender. Because in the village meeting most of the time we only discuss the technical things, such as who will handle the projects, should the village's officials took part in the project or just be an observer, how much will it costs, etc. So, in the end, we just lost the moment, or the program just does not work."

Many research stated that there are many reasons for the (dis)trust. Those research argue that trust arises from partners' competence, which includes technical skills, experience, and reliability (as cited by Cornnelly et al., 2015). Hill \& Lineback [9] argue that to build trust, competence is the key. They argue that competence should cover technical knowledge, operational knowledge, and political knowledge. Technical knowledge related to the understanding of how to perform work and basics management. Operational knowledge refers to the realization of technical knowledge, so it covers not what to do things but how to do things. While political knowledge covers the skill to get what is being wanted, understand how to justify specific action or request.

In the context of this study, the competence of the VOE's managers should cover their understanding of their job description, real action to do the job and persuasive skills to make the plan into realization. When in fact, the village government does not seem to trust the VOE manager indicating that there is no competence in place. It might be due to the fact that many VOE managers are not business professionals. They have no previous experience in managing the business. Their basic management skill, therefore, is questionable. Many of them are also not a prominent figure in the village.

This condition quite paradoxical, however, because, the VOE managers should be chosen not only by the village officials but also approved by the society. As being stated by the Law, the village meeting is an important forum where the VOE manager's selection process should be discussed and approved. When the chosen VOE managers do not seem to satisfy the village officials, it indicates there is something wrong with the process. This finding, lead us to dig more about the process of VOE managers' selection.

Regarding the VOE manager selection, we found that the VOE managers' lack of competencies cannot be separated from bungling election process. The election process does not base on competence. One of our interviewee, the Leader of VOE Forum, approved this, he stated that:

"The basis to choose VOE managers are not clear. It happens carelessly. Why careless? Because truthfully, many of village officials do not really understand what is VOE. They just know that every village should establish VOE was stated in the Law, so they just do it as a formative action to abort the obligation. So, because the process was like that, the VOE management was also formed carelessly".

The consequence of the careless VOE management formation impacting to the poor performance. Many of the VOE managers do not know what their duties and responsibilities are and what they 
supposed to do with the jobs. This lack of technical and operational competence lead to the distrust by the village officials.

Further, the condition is getting worse, because there are also many villages that do not have a solid village development master plan. Let alone the master plan, when the village officials were being asked what the village potential are, they were not sure how to answer that. They find it difficult to make a solid profile about the village, what is actually the potential village priority. When being asked what the village priority development is, one of our interviewees said:

"Our village potentials are varied. We have plans to develop a tourism village because we have river flows that pass through our village. So, we have plans to make rafting tours. We also have many chicken farmer, so we want to help them in terms of capital sharing. In our village there are also many motorcycle repair shop, so we want to enlarge their work scale. We also have a plan to make a tent rental service, because if there is a marriage celebration or recitation celebration, our people can rent it from us (village government). Our village is also very well known for its traditional vegetable soup, called lodeh. It is the best in the district."

Many village officials were also stated similarly. It is difficult for them to choose their village development plan and it made them precarious in choosing the right type of business for their VOE's. If we would like to see this story from the bigger perspective, blaming VOE managers alone because of lack competence issue, is not fair. Village officials are also taking part in making this vicious circle do not meet its end. This is not a causality relationship where one cause is impacting other cause, but it is more like a reciprocal relationship. In other words, we cannot say that the lack of competence is causing the distrust or vice versa, but that the lack of competence and distrust are causing each other.

The solution toward this problem is nothing then improving the competence, especially VOE management team, as they are the one who will managed and face daily basic activities. In this notion, we argue that improving competence should also be specific for effectivity and efficiency. The competence improvement program should cover the management training program and businessrelated program. Management training program is needed because many of the VOE management team members are not professional, they should be given the training that covers managerial skill and leadership. In the program they learn how to make decision, how to establish solid teamwork, resolve conflict and how to lead a project. Business-related programs also needed as they are facing the technical problems related to the business development.

Aside from the problematic trust between the village leader and VOE management, the fact that both parties do not understand fully each rights and obligations make the situation even worse. The idea to put VOE as independent and professionally-managed economic institution seems to be the talk only. The reality is the village leaders do not want to lose sight on VOE activities not only caused by the excuse that VOE management needs directions but because the village leaders think that it is their job to interfere the upstream to downstream VOE activities.

"I believe that in this initial stage, the VOE management needs guidance and directions, but I do almost everything. Say, the initiative process was come from me, I give them the business ideas, many business ideas. I went to other villages to do comparative studies. I want to learn from them who had proven to be successful in managing VOE. But when I got back to my villages, I share what I know to the VOE management them, hope that they will respond actively, but no, they just make wait passively, waiting for a commando".

We make clarification about that statement to the VOE management team, and they respond differently. According to them, what makes the VOE activities has not run yet, or just going nowhere, is because they believe that they have to wait for the directions or commando from the village leader. 
"We are waiting for the command, we believe that it is the best for now. We are not going to take the risk by doing activities without approval. It is also something that we have been agreed together. Every business ideas should be approved by the village officials. They are the ones who know how much money we have, when the money will be allocated to us".

The structural vagueness within the VOE contribute to the late progress of the VOE establishment. This might due to the lack of understanding of rights and obligations among parties. We argue that village leaders assume that $\mathrm{VOE}$ is a project under their authority in which its management and activities are also under their control. In other hand, the VOE management think that they are just operational manager who do technical activities only. They are not aware that VOE management is expected to be the one who manage the entire activities of VOE professionally, while the village leader only serves as the advisor.

We cannot separate this phenomenon with paternalistic culture that might be contrary to the spirit of VOE autonomy. The village leader propensity to direct is reasonable. However, too many directions and restrictive actions has burdened VOE management in designing the VOE business plans, instead of assisting them toward smooth and real implementation.

\subsection{Fostering Trust}

Many types of research showed the importance of trust in an organization. Jiang, Henneberg, and Naudè [12] stated that trust has a positive influence on long-term orientation in business relationships. Therefore, they argue that trust is important not only in the early stage of business development but it is important to be sustainably managed by the management and the business partner. Trust is also very crucial for open innovation. Brockman, Khurana, and Zhong [5] argue that societal trust serves as an effective mechanism for improving relational governance among partners, thereby leading to better collaborative outcomes. Financial performance will result in higher managerial performance if it is mediated by interpersonal trust. Those researches put trust as an important factor in organization activities and to generate the desired output.

In the government context, especially democratic governance, trust is a prerequisite. Schlesinger and Heldman [16] argue that in order for the public administration to function smoothly and effectively, the government needs public trust. Lewicki and Tomlinson [14] support the notion that trust is an essential ingredient in the building of a competent state and helps to build good governance. Jennifer and Jennifer [11] report that public trust towards local government is higher than to the national/central government, though they do not neglect the importance of trust both in local and central government. The higher trust towards the local government compared to central government is due to the better understanding of political issues and that people feel most politically effective. Much of the actions done by the local government are in a reach of the people, they learn about the distant decisions of the local government leader from first-hand interactions so that people are more likely to interact with them.

The previous studies have been supported the argument of the importance of trust for effective organizations. In the context of this study, we also found that what might hamper the effectiveness and inefficiency of the VOE establishment is due to the lack of trust. The next important question, therefore is, how we foster trust among the village elements, more specifically between the village government officials and VOE management?

To answer that question, first, we must understand the nature of the relationship between village government official (leader) and VOE management? Do they are in the same position or the other is in the upper position towards another? Understanding the nature of the relationship is important to create an effective strategy.

According to the Village Law, the VOE management must be responsible to the Village Leader (Kepala Desa/Kades) regarding the VOE activities. It means that the relationship between those two parties is not equivalent. The village leader have a higher position, not only because the VOE 
management gives a report to them, but also in a sense that the village - leads by the village leaderhave greater number of shares proportion compared to other parties. Does, then, the affiliation portrayed investor-management relationship? To the best of our understanding, the relationship between village leader and VOE management should not be treated under the principal-agent theory, where the agent serves the interest toward the agent. For some extent, it might be correct to conclude that type of relationship, that village government shares being put in VOE can be considered as an investment, does put the village as the investor and VOE management as the agent. However, the relationship is more complicated than that. The village leader is placed not only as an investor but as facilitator and advisor.

Financial and Development Supervisory Agency (Badan Pengawas Keuangan dan Pembangunan/BPKP) divide the structure of VOE into three parties; advisor, is served by village leader; operational management is the VOE management; and supervisor served by village consultative assembly (Badan Permusyawaratan Desa). As advisor, village leader's job is to provide information and assistance. The village leader may assist VOE management by comunicating with them to understand the situation within VOE, acting as a sounding board, helping the VOE management to explore options to resolve certain situation and empowering the VOE management to decide which option/s that might be best to pursue. Based on this description, the dyadiac relationship between the village leader and VOE management is not only about money (capital) allocation that serves village leader as an investor but also about coordination-assistance between the advisor and the advisee.

To foster the trust in that type of relationship, study by Argento and Peda [1] might be a meaningful source. In the study, they stated that to foster trust, local government can use contracts either as a substitute or complement to trust. However, which can be either be substitutes or complements, is contingent upon the capacity of interacting individuals involved. Six [17] argue that trust and contract are complements, as they can coexist and reinforce each other. Contracts may also serve the various functions of coordination and as a sign of a credible commitment from both parties [20]. The notion of trust as the contract as the complement is also supported by Dekker and Broek [8]. In his study, he admits that trust complement formal control mechanism to a certain threshold. As a legal form, contracts can support trust development within organization [2]. Those arguments speak for contract as the complement of the trust.

Different opinion stated by Vosselman and Van der Meer-Kooistra [19], according to them, contract is a substitutes for trust. They argue that if there is trust between parties, then contract is not needed. However, the use of tight contract is advocated when low or no trust exist. In this context, when trust is in place between parties, then contract is an optional. But the problem with this argument is that there is no single benchmark to measure the trust. We tend to believe that contract complementing the trust, not substituting it. We believe that contract plays the role to foster the trust as it bind the parties to commit with specific roles and obligations.

Not only contractual agreement which seen as the tool to fostering the trust, a study by Becerra and Gupta [3] stressed the importance of communication frequency in the dyadic relationship between trustor and trustee. They argue that when the communication between trustor and trustee is frequent, their relative interest and specific linkage to the organization are now more apparent to both of them and therefore have a greater effect on how both trustor and trustee behave within their dyadic relationship. Argento and Peda [1] agree to this notion. In particular, they stated that interactions frequency among individuals within organization play a role in the dynamics of trust and therefore also impact the contractual needs. When the individuals have frequent interactions, within both official and informal settings, the contract might be loose, on a contrary when there is less interactions then the contract is tight used as a control tool.

We propose a framework for analyzing the relationship between trust and contract. Specifically, when contract can plays as a substitute or as a complement. Framework depicted in figure 1 suggest in-depth understanding of trust-contract as a fostering-trust mechanism can be achieved through 
examining how the interactions and the competence as variables between trust vis-à-vis contract and add plays as a complement or substitute.

$\begin{array}{lccc} & \begin{array}{c}\text { Trust Substitute } \\ \text { Contract }\end{array} & \begin{array}{c}\text { Trust Complement } \\ \text { Contract }\end{array} & \begin{array}{c}\text { Contracts Substitute } \\ \text { Trust }\end{array} \\ \text { Mutual Trust } & \text { High } & \text { Low } & \text { Tight } \\ \text { Contract } & \text { Loose } & \text { Low } \\ \text { Interaction Frequency } & \text { High } & \text { Low } \\ \text { Competence } & \text { High } & \end{array}$

Figure 1.

Framework of the Relationship Between Trust and Contract

\section{Conclusion}

Our research show that one of the factors that hamper the establishment of VOE is the distrust from the village leader towards the VOE management. This distrust is because the village leader perceived the VOE management is lack of competence. We believe that improving the competence in terms of managerial skills, leadership and business-related skills is important and in terms of fostering trust, contracts can play as a complement toward trust. For a village with a low mutual trust between the village leader and VOE management, contract can place as the substitute. Binding related parties in a contractual agreement may one of a strategic tool to answer the lack of rights and obligations understanding between two parties. Contractual agreement may serve as a solution in which each duties, obligations even punishment and reward are stated. This mechanism, we believe will fill the vacuum of trust within the VOE.

\section{Acknowledgment}

The authors appreciatively thank to the BUMDes managers and village leaders in Banyumas region for their support, assistance and information during the research project. The authors also would like to gratefully thank to the Lembaga Penelitian dan Pengabdian Masyarakat (LPPM) Universitas Jenderal Soedirman for funding of this research project.

\section{References}

[1] Argento, D., \& Peda, P. (2015). Interactions fostering trust and contract combinations in local public services provision. International Journal of Public Sector Management, 28(4/5), 335-351.

[2] Bachmann, R., \& Inkpen, A. C. (2011). Understanding institutional-based trust building processes in inter-organizational relationships. Organization Studies, 32(2), 281-301.

[3] Becerra, M., \& Gupta, A. K. (2003). Perceived trustworthiness within the organization: The moderating impact of communication frequency on trustor and trustee effects. Organization Science, 14(1), 32-44.

[4] Bone, H. (2017). The effects of financial and non-financial performances towards the managerial performances with interpersonal trust as a mediation variable. International Journal of Law and Management, 59(6), 1190-1202.

[5] Brockman, P., Khurana, I. K., \& Zhong, R. I. (2018). Societal trust and open innovation. Research Policy.

[6] Carter, N., Bryant-Lukosius, D., DiCenso, A., Blythe, J., \& Neville, A. J. (2014). The Use of 
[7] Connelly, B. L., Crook, T. R., Combs, J. G., Ketchen, D. J., \& Aguinis, H. (2018).

Triangulation in Qualitative Research. Oncology Nursing Forum, 41(5), 545-547. https://doi.org/10.1188/14.ONF.545-547

Matters More? Journal of Management, 44(3), 919-945.

https://doi.org/10.1177/0149206315596813

[8] Dekker, P., \& Broek, A. (2004). Civil society in longitudinal and comparative perspective: voluntary associations, political involvement, social trust and happiness in a dozen countries. In Proceedings of the 6th International Conference of the International Society for Third-sector Research: Ryerson University, Toronto.

[9] Hill, L., \& Lineback, K. (2012). To build trust, competence is key. Harvard Business Review.

[10] Jamil, I., \& Askvik, S. (2015). Citizens' Trust in Public and Political Institutions in Bangladesh and Nepal. In Governance in South, Southeast, and East Asia (pp. 157173). Springer.

[11] Jennifer, F., \& Jennifer, W. (2014). The roots of trust in local government in Western Europe. International Political Science Review.

[12] Jiang, Z., Henneberg, S. C., \& Naudé, P. (2011). The importance of trust vis-à-vis reliance in business relationships: some international findings. International Marketing Review, 28(4), 318-339.

[13] Jones, S. L., \& Shah, P. P. (2016). Diagnosing the locus of trust: A temporal perspective for trustor, trustee, and dyadic influences on perceived trustworthiness. Journal of Applied Psychology, 101(3), 392.

[14] Lewicki, R. J., \& Tomlinson, E. C. (2003). Trust and trust building. Beyond Intractability, $114-139$.

[15] Mayer, R. C., Davis, J. H., \& Schoorman, F. D. (1995). An integrative model of organizational trust. Academy of Management Review, 20(3), 709-734.

[16] Schlesinger, M., \& Heldman, C. (2001). Gender gap or gender gaps? New perspectives on support for government action and policies. Journal of Politics, 63(1), 59-92.

[17] Six, F. (2013). Trust in regulatory relations: How new insights from trust research improve regulation theory. Public Management Review, 15(2), 163-185.

[18] Srirejeki, K. (2018). Empowering the role of village owned enterprises (BUMDes) for rural development: case of Indonesia. Jurnal Akuntansi Manajemen Dan Ekonomi, 20(1), 510.

[19] Vosselman, E., \& Van der Meer-Kooistra, J. (2009). Accounting for control and trust building in interfirm transactional relationships. Accounting, Organizations and Society, 34(2), 267-283.

[20] Woolthuis, R. K., Hillebrand, B., \& Nooteboom, B. (2005). Trust, contract and relationship development. Organization Studies, 26(6), 813-840. 